\title{
An Explorative Study of Financial Manipulation of Working Women through Discourse
}

\author{
Uzma Sadiq \\ Assistant Professor, Department of English \\ University of Education Lahore, Campus D.G.Khan \\ uzma.sadiq@ue.edu.pk \\ Dr. Nazia Suleman \\ Assistant Professor, Department of Humanities \\ Comsats University Islamabad Vehari Campus \\ naziasuleman@ciitvehari.edu.pk \\ Asra Khan \\ Phd Scholar and Visting Faculty Member \\ Bahauddin Zakariya University Multan \\ asrakhan886@hotmail.com
}

\begin{abstract}
The present study aims to find out the role of language in financial manipulation of working women. Financial manipulation refers to the unfair use of someone's labor and financial resources. The study population comprises of the working women serving in the provincial government departments located in Dera Ghazi Khan Division in the province of Punjab, Pakistan. The sample size of 150 working women through purposive sampling technique is taken for study, and a self-administered questionnaire was served through convenience sampling technique. Dijik's (2006) idea of manipulation through discourse as appeared in Discourse and Manipulation is taken as theoretical framework for the study. The data is analyzed quantitatively using SPSS.The study concludes that the working women in South Punjab, Pakistan are manipulated financially through various linguistic tools as they intentionally ignore their own needs in order to save family relations and to avoid sarcastic remarks. The study can be helpful for further research to be carried out in the field of women empowerment in society. It can pave the way for future study in the use of language as a tool of manipulation.
\end{abstract}

Key Words: financial, manipulation, working women, discourse, victims

\section{Introduction}

Every human being aspires to have pleasures of life. In order to get their dreams come true, people work and try to find new avenues of progress. In the present world, women are also working as individuals and bringing meaning to their lives. Most of the women in urban areas are lucky enough to get education and work in various walks of life so as to utilize their knowledge and skills. Many of them who are working outside of their homes are envied by the unemployed women as the happiest creatures on earth as they are free to work and free to earn. But the other side of the coin discloses the dark side of the picture. The women aim to work and earn for a 
better life style but in most of the cases their finances are controlled by the male members at their homes, be they their fathers, brothers, husbands or sons. This type of manipulation is frequently carried out in a straightforward and open way. The women are made afraid of stereotypes and a wide range of tactics is employed by the aforementioned patriarchs. One of these tactics is discourse that helps in developing and disseminating ideologies in various social contexts. The study is carried out to explore the way women in South Punjab, Pakistan are manipulated and to make them aware of this manipulation so as they are able to speak about their needs and counter the various forms of manipulative discourses. The paper is organized into sections like Introduction; Objectives of the study; Significance of the study; Research Hypothesis; Litearture Review; Theoretical Framework; Research Methodology; Data Analysis and Conclusion.

\section{Objectives of the Study}

The objectives of the present study are:

i. To explore the reasons behind women's financial manipulation.

ii. To find out how the working women are trapped into the alluring web of discourse that leads them to ignore their own needs and put their income in the hands of male members of family

\section{Significance of the Study}

The present study is significant as it underpins the exploitation of well educated working women whoare fully acquainted with their rights yet they become victims as they find themsleves helpless in front of stereotypical discourses of the society. The practical significance of the study is that it may help the working women understand the social and cognitive manipulation that they experience unconsciously. The study may enlighten the minds of male members of the society in recognizing the working women as individuls and paying heed to their sufferings and deprivation.

\section{Research Hypothesis}

The study postulates the hypothesis that in context of Pakistan, the working womenconsciously or unconsciously fall a victim to the financial manipulation in order to be accepted and adjusted in the family where the male members take the charge of all decisions especially related to money. In this regard, language is employed as a tool of persuasion and manipulation.

\section{Literature Review}

According to Miller (1995), the types of non-physical abuse experienced by women include psychological, economic, social and emotional ones. He has shown that the economic abuse involves victim to be economically dependent on the 'perpetuator'. It includes restricting the use of financial resources and refusing the power to women to take any finance related decision. Evan (2007) has described that in more than half of the abusive relationships women are denied an access to capital resources and are made financially dependent.Sharp (2008) has evaluated the issues women face as a result of economic abuse.She has also illustrated that when women leave their partners due to the financial abuse, they face problems regarding employment, housing, child maintenance and lack of financial resources for which they become dependent on the abuser who is the 'Provider' as well. Financial manipulation may include the cases when men take financial debts in the name of their partners without their consent and women feel being domestically abused due to the debt issues they face (Lyon, 2002, Brewster, 2003). Wilcox (2006) has described that when women are not supported financially by their partners or are deprived of their money, they have to take small debts to pay their bills which in turn create problems for them. Husain and Dutta (2014) described that the incorporation of women in development is important as are the ways to do this. These relations illustratewhether the abilities of women used 
in the development of community, are being developed or repressed.Jury, Thorburn and Weatherall(2017) have described that how women in Aotearoa, New Zealand, face economic abuse. They conducted a survey and analyzed the responses of 398 respondents. The results declared that the economic abuse towards women originated due to the hegemonic construction of male as the "provider" and it also includes the restriction of freedom of victims.

Chowbey (2017) conducted research taking84 married women from Britain, India and Pakistan as sample for the study. She has highlighted different kinds of economic abuse of women that include preventing women from acquiring and using the resources, manipulating their resources and refusing them from contributing. There are certain other abuses as well that are related to particular context like manipulating women marriage gifts and long-term finances. She has also described the types of strategies that the women employ to deal with the economic abuse. Qureshi (2016) explored the reasons of the failure of marriages of Pakistani women in Britain and concluded that the finance was the major cause behind the collapse of 40 out of 59 marital relations.

Rabbani, Qureshi and Rizvi (2008) studied the various forms of domestic violence done to the victims in Karachi. It came out that the husbands used tactics like refusal to pay the utility bills and stealing the jewels of women. The women in South Asia are economically far behind the menas they have less opportunities of employment and have less control on the use of their own income (Bhan, 2001; Nandi and Platt, 2010; Kishor and Gupta, 2009). Smart (2007) suggests that research on economic abuse should bring into the account the way the couples negotiate about financial resources and the way they view the importance of financial relations among them.

The studies carried so far explored the financial abuse of women in cases where the women are fully conscious of the fact that they are manipulated but there are also the cases of manipulation when the women become suffererswillingly as with the help of linguistic strategies they are made to accept certain roles that they would not have accepted otherwise.

\section{Theoretical Framework}

The present study takes Dijik's (2006) Discourse and manipulation as theoretical framework. Dijik (2006) is of the view that manipulation works at three levels: Social, Cognitive and Discursive. Socially people are dominated by social inequality; cognitively the minds of the people or the groups are controlled by various modes of understanding and ideologies; anddiscursively the dominant group keeping in view its own interest declares certain things asgood and some as bad ones. At all these levels, discourse is employed as tool formanipulation. "Manipulation implies the exercise of a form of illegitimate influence bymeans of discourse" (Dijik,2006). The manipulator plays with words and inculcates certainnotions in the minds of the people who in turn become passive recipients and victims ofmanipulation as they cannot comprehend the intentions of the manipulator (Wodak, 1987). In the case of working women, the dominant male members of family usually exercise power andcontrol the financial possessions of women.

\section{Research Methodology}

The data for the present study is collected from 150 women working in various departments of Punjab Provincial Government in D.G. Khan Division. The data was collected through purposive sampling technique.The aim of taking these women as sample for study is to explore how far the well-educated and independent women in a district of South Punjab Pakistan, are free and independent in utilizing their earnings. The survey for the study comprised of various constructs including demographic information.Keeping in view the situation, the questionnaire was 
comprehensive in order to gather information related to the responsibility of women towards earning; theirwilling or unwilling contribution to household expenditures, the part of income that they spend on themselves; the reactions that they have to face while spending money on family; the controlling hand offinances in the family, linguistic tactics employed to take hold of women's income and finallyhow they get reflective when all their income is spent by someone else from the family.The data is analyzed quantitatively with the help of SPPS and the responses of the subjects are analyzed with the help of Dijik (2006)'s approach of discourse and manipulation.

\section{Data Analysis}

Finance is the core need for survival of human beings and for an active participation in the established social system of the world. It is being observed that women have internalized their duties to earn and to contribute to the financial matters of the family. However the male members of family do impose decisions particularly related to finance owing to the supreme social status that they enjoy. The women are realized of their duties towards their homes and families and their own needs are put on least priority.

Table 1: Contribution to house expenditure

\begin{tabular}{|l|l|l|l|l|}
\hline & Frequency & Percent & Valid Percent & $\begin{array}{l}\text { Cumulative } \\
\text { Percent }\end{array}$ \\
\hline Willingly & 120 & 80.0 & 80.0 & 80.0 \\
\hline $\begin{array}{l}\text { Unwillingly } \\
\text { force to do so }\end{array}$ & 10 & 6.7 & 6.7 & 86.7 \\
\hline $\begin{array}{l}\text { you are the sole } \\
\text { earner }\end{array}$ & 16 & 2.7 & 2.7 & 89.3 \\
\hline Total & 150 & 10.7 & 10.7 & 100.0 \\
\hline
\end{tabular}

The table 2 demonstrates that $80 \%$ of the respondents are willingly spending on their families and $6.7 \%$ respondents have shown that they are contributing in the household expenses unwillingly while $2.7 \%$ are forced to contribute in the household expenses and $10.7 \%$ of the total respondents are the solo earners in families. The table demonstrates the fact that the highest percentage goes with the women who are spending willingly which counters the fact that they have accepted their role as an earner and a contributor to family finances.

The obvious indicator as noticed in the study is that the female partners are being ignored in the decision making process which is a form of dispossession and depriving women of the fundamental rights to give their inputs. This is represented via various discourses. Although the females are earning and contributing towards household expenditures yet they have to sense a feeling that they are not the owners as they cannot even spend with their own choice.

Table 2:The pleadingthat the women give when they shop for themselves

\begin{tabular}{l|llcll} 
& & Frequency & Percent & Valid Percent & $\begin{array}{l}\text { Cumulative } \\
\text { Percent }\end{array}$ \\
\hline $\begin{array}{l}\text { I bought it } \\
\text { because } \mathrm{i} \text { was in } \\
\text { the need of it }\end{array}$ & 76 & 50.7 & 50.7 & 50.7 \\
$\begin{array}{l}\text { I bought it } \\
\text { because I liked it }\end{array}$ & 67 & & & \\
I bought it & 7 & 44.7 & 44.7 & 95.3 \\
\end{tabular}


because I had some money

Total
150
100.0
100.0

The table depicts the tendency of giving justification on the part of women when they purchase something for themselves.50.7\% of the respondents bought the things as they were in the need of it and only $4.7 \%$ of them bought the things as they were having money and $44.7 \%$ women bought the things and justified their act by saying that they liked those items, therefore they purchased them. The highest ratio goes to the statement when the women justify their shopping under the core of need. As most of the women were afraid that they were considered spendthrift, so they have to pretend that the purchased items are the need of them or that of the family.

Table 3: How do women spend?

\begin{tabular}{llcll}
\hline & Frequency & Percent & Valid Percent & $\begin{array}{l}\text { Cumulative } \\
\text { Percent }\end{array}$ \\
\hline $\begin{array}{l}\text { In consultation } \\
\text { with husband }\end{array}$ & 70 & 46.7 & 46.7 & 46.7 \\
\hline $\begin{array}{l}\text { Independently } \\
\text { In consolation }\end{array}$ & 34 & 29.3 & 29.3 & 76.0 \\
with family & & 24.0 & 24.0 & 100.0 \\
\hline Total & 150 & 100.0 & 100.0 & \\
\hline
\end{tabular}

This table demonstratesthe fact that how much the women are contributing towards household and who is the controlling hand. In case of married women, husband takes control of the money and $46.7 \%$ of the total population spend their money in consultation with their husbands and only $29.3 \%$ are spending it independently.

The males memebers being the dominant and influential persons at home take all the decisions related to finance. The women are deprived of the basic essentials and their finances are consumed for the household expenses. They have put their personal needs on secondary position.

Table 4: Percentage of women spending on themselves

\begin{tabular}{lllll}
\hline & Frequency & Percent & Valid Percent & $\begin{array}{l}\text { Cumulative } \\
\text { Percent }\end{array}$ \\
$\begin{array}{l}\text { 10-20\% of your } \\
\text { income? }\end{array}$ & 31 & 34.0 & 34.0 & 34.0 \\
$\begin{array}{l}\text { 20-30\% of your } \\
\text { income? }\end{array}$ & 32 & 21.3 & 21.3 & 55.3 \\
$\begin{array}{l}\text { 30-40\% of your } \\
\text { income? }\end{array}$ & 29 & 19.3 & 19.3 & 74.7 \\
$\begin{array}{l}\text { 40-50\% of your } \\
\text { income? }\end{array}$ & 27 & 18.0 & 18.0 & 92.7 \\
$\begin{array}{l}\text { Whole } \\
\text { Total }\end{array}$ & 11 & 7.3 & 7.3 & 100.0 \\
\hline
\end{tabular}

The table 4 demonstrates the percentages of income that the working women are spending on themselves. 34\% percent of the respondents expressed that they spend 10-20\% of their income on 
themselves which is ameager amount of their salaries. $21 \%$ of the working women spent $20-30 \%$ of their income, $29 \%$ women spent $30-40 \%$ and only $18 \%$ of these respondents spent $40-50 \%$ of their income according to their own will and for themselves. Quite surprising is the fact that only $7 \%$ are of the view that they spent whole salaries on themselves.

Table 5:The reason women spend less on themselves

\begin{tabular}{lllll}
\hline & Frequency & Percent & Valid Percent & $\begin{array}{l}\text { Cumulative } \\
\text { Percent } \\
\text { you spend on }\end{array}$ \\
$\begin{array}{l}\text { yashion only } \\
\text { you take care of }\end{array}$ & 40.7 & 40.7 & 40.7 \\
$\begin{array}{l}\text { yourself only } \\
\text { you are ignorant } \\
\text { of family } \\
\text { financial issues }\end{array}$ & 47 & 31.3 & 31.3 & 72.0 \\
$\begin{array}{l}\text { You don't take } \\
\text { care of } \\
\text { anyone else }\end{array}$ & 26 & 10.7 & 10.7 & 82.7 \\
\hline
\end{tabular}

Table.7 addresses the reason behind womens spending less on themselves. It came out that they were afraid of the comments like 'you spend so much on fashion', 'you take less care of the family' or 'you are ignorant of the needs of the family'. To Dijik (2006), these linguistic strategies insert an illegitimate influence on the people that inculcated a sense of fear in working women and acted as a tool in the financial manipulation of them. They are depressed psychologically and exploited emtionally as well. The women put their own necessities in the background and assume the charge of spending their financial resources on familiess. The $40.7 \%$ of the total population were afraid of torturing comments related to fashion, $31 \%$ of the working women were afraid of being accused of spend thrift or selfish.

Table 6: How many women go to the bank to withdraw their salaries?

\begin{tabular}{lllll}
\hline & Frequency & Percent & Valid Percent & $\begin{array}{l}\text { Cumulative } \\
\text { Percent }\end{array}$ \\
Yes & 67 & 44.7 & 44.7 & 100.0 \\
No & 83 & 55.3 & 55.3 & 55.3 \\
Total & 150 & 100 & 100 & \\
\hline
\end{tabular}

Table 6 demonstrates that $55.3 \%$ of the working women were not going to the banks to withdraw the cash that reflected the fact that they were the indirect recipients of their income. It all now depends on the one who withdraws the amount to give these women their whole income or to give a slice of it.

Table 7: The reason behind women going to the bank to withdrw salaries

\begin{tabular}{lllll}
\hline & Frequency & Percent & Valid Percent & $\begin{array}{l}\text { Cumulative } \\
\text { Percent }\end{array}$ \\
$\begin{array}{l}\text { you } \\
\text { independent }\end{array}$ & 107 & 71.3 & 71.3 & 71.3 \\
$\begin{array}{l}\text { you want to keep } \\
\text { your }\end{array}$ & 9 & & & \\
\hline
\end{tabular}




\begin{tabular}{|c|c|c|c|c|}
\hline \multicolumn{5}{|l|}{ income } \\
\hline $\begin{array}{l}\text { you don't like } \\
\text { interference of } \\
\text { anybody else }\end{array}$ & 11 & 7.3 & 7.3 & 84.7 \\
\hline $\begin{array}{l}\text { No other person is } \\
\text { there to } \\
\text { do this task }\end{array}$ & 23 & 15.3 & 15.3 & 100.0 \\
\hline Total & 150 & 100.0 & 100.0 & \\
\hline
\end{tabular}

The table 7 illustrates the reason that some of the working women go to the banks and withdraw their salaries.71.3\% of the respondents are of the view that they enjoy a sense of freedom when they withdraw their salaries without taking help from any male member of the family. Only $6 \%$ of the respondents were fond of keeping their income with themselves and $15.3 \%$ went to the banks because there was no one else at home to do the task.

Table 8: The reasons of women not going to the bank to withdraw salary

\begin{tabular}{|c|c|c|c|c|}
\hline & Frequency & Percent & Valid Percent & $\begin{array}{l}\text { Cumulative } \\
\text { Percent }\end{array}$ \\
\hline $\begin{array}{l}\text { Yourhusband/father/brother } \\
\text { says "I am there to go to } \\
\text { the } \\
\text { bank/to do this task" }\end{array}$ & 124 & 82.7 & 82.7 & 82.7 \\
\hline $\begin{array}{l}\text { You are afraid of words } \\
\text { "you go on roaming about" }\end{array}$ & 18 & 12.0 & 12.0 & 94.7 \\
\hline $\begin{array}{l}\text { You will listen to the words } \\
\text { "women should avoid } \\
\text { going } \\
\text { to the bank" }\end{array}$ & 8 & 5.3 & 5.3 & 100.0 \\
\hline Total & 150 & 100.0 & 100.0 & \\
\hline
\end{tabular}

The working women who have responded to the given set of questions are assumed to be incapable of withdrawingtheir own salary from the banks $82.7 \%$ women are of the opinion that they are not allowed to go to the bank because of various social stereotypes like if a man is at home there is no need of a woman going out and visiting banks to withdraw the amount. This linguistic strategy suppresses the first feeling of independence in women. Dijik(2006) claims that the manipulator take helps from discourse and makes the manipulated ones believe and accept certain notions that are in the interest of the manipulator. The working women have to experience the discursive type of manipulation when the male members of family announce the objective roles of women by not allowing them to visit banks to withdraw their salaries.

The study has explored the fact that men used to impose the structural means of deprivation upon women such as withholding of money and dealing with bank accountswhich results in regulating their actions of daily lives. This sort of control is not only visible in domestic matters but also in economic subjugation such as their income, how to spend it etc. The analysis also resonated with the abuse that how women are abused economically and are deprived of the fundamental rights and freedom. 
Gender plays a significant role in power decision and the same goes with political system too. Inthis vein, women have been continuously exploited socially, cognitively and economically. The economic oppression of the women in today's scenario goes in alignment with the gender stereotypes. The financial exploitation results when the men of family (brother, father, husband) use women to earn finances for them and later on they themselves become the custodian of those earnings. Littwin (2012) also explains the three types of men who strives to achieve the financial control are:

- Holding of bank accounts of females

- Hold of women's money

- An allowance of money to the women

Table 9: Reasons for contributing to household expenditure

\begin{tabular}{lllll}
\hline & Frequency & Percent & Valid Percent & $\begin{array}{l}\text { Cumulative } \\
\text { Percent }\end{array}$ \\
$\begin{array}{l}\text { You are highly } \\
\text { appreciated }\end{array}$ & 32 & 21.3 & 21.3 & 21.3 \\
$\begin{array}{l}\text { You are given } \\
\text { Importance }\end{array}$ & 21 & & & \\
you face criticism & 3 & 14.0 & 14.0 & 35.3 \\
$\begin{array}{l}\text { you feel it your } \\
\text { responsibility }\end{array}$ & 94 & 2.0 & 2.0 & 37.3 \\
Total & 150 & 62.7 & 62.7 & 100.0 \\
\hline
\end{tabular}

The women who are contributing are being exploited by varied means as $21.3 \%$ are appreciated linguistically and $62.7 \%$ are made to realize that it is their duty to contribute to the financial matters of family. To Dijik (2006), this is a form of cognitive manipulation as various ideologies are inculcted in the minds of women and patriarchs at home, keeping in view its own interest ,declare the duties of women to contribute to demestic finances.

Table 10: You spend because you come across comment, 'You earn so you have to spend upon family'

\begin{tabular}{lllll}
\hline & Frequency & Percent & Valid Percent & $\begin{array}{l}\text { Cumulative } \\
\text { Percent }\end{array}$ \\
Yes & 99 & 66.0 & 66.0 & 34.0 \\
No & 51 & 34.0 & 34.0 & 100.0 \\
Total & 150 & 100.0 & 100.0 & \\
\hline
\end{tabular}

It came out that the working women were accepting their duties to earn and spend on family as a duty. The linguistic strategies employed by men at family have naturalized the duties of women. The working women are constantly reminded that they are earning that is why they have to spend on household activities. $34 \%$ of the respondents refuted the idea that they come across any such comment, but $66 \%$ of them affirmed the statement. This again is illegitimate assertion of power and controlling of minds of working women through discourse. 
Journal of Business and Tourism

Volume 06 Number 01

January - June, 2020

Table 11: Linguistic tactics employed to make women spend on family

\begin{tabular}{|c|c|c|c|c|}
\hline & Frequency & Percent & Valid Percent & $\begin{array}{l}\text { Cumulative } \\
\text { Percent }\end{array}$ \\
\hline you spend on yourself only & 38 & 25.3 & 25.3 & 25.3 \\
\hline you are spendthrift & 20 & 13.3 & 13.3 & 38.7 \\
\hline $\begin{array}{l}\text { you are responsible to } \\
\text { spend on family }\end{array}$ & 92 & 61.3 & 61.3 & 100.0 \\
\hline Total & 150 & 100.0 & 100.0 & \\
\hline
\end{tabular}

In this table $61.3 \%$ of the total respondents are made responsible to spend money to counter the needs of the family and the linguistic means in form of criticsm are employed. To Dijik (2006), this type of manipulation takes place at cognitive level. In case of working women, the male members of family exert their power of discourse to threaten women psychologically.

Table12: Women spend because they are appreciated in words:

\begin{tabular}{lllll}
\hline & $\begin{array}{l}\text { Frequenc } \\
\text { y }\end{array}$ & Percent & Valid Percent & $\begin{array}{l}\text { Cumulative } \\
\text { Percent }\end{array}$ \\
$\begin{array}{l}\text { You are so good because } \\
\text { spend in family }\end{array}$ & 31 & 20.7 & 20.7 & 20.7 \\
$\begin{array}{l}\text { You are the best } \\
\text { wife/daughter/sister }\end{array}$ & 32 & 21.3 & 21.3 & 42.0 \\
You are a responsible lady & 87 & 58.0 & 58.0 & 100.0 \\
Total & 150 & 100.0 & 100.0 & \\
\hline
\end{tabular}

The power of discourse in financial manipulation of women is not always so distinct. Women are stereotyped as emotional beings that can be easily exploited through admiration. The respondents of the survey were well educated and working on distinguished posts. In such a case, the manipulation is not always so simple. They are appreciated and their contribution to family expenditure is acknowledged that makes these ladies work happily and accept their roles happily. Only $20.7 \%$ of the respondents selected for the study were appreciated in a straightforward way for spending on family and $21.3 \%$ of them were acknowledged as the best wives, sisters, mothers or daughters. The highest ratio of $58 \%$ was noted when the women were appreciated with the words that they are the responsible ladies. It came out that the women are appreciated less for other traits as much as they are admired for being the most responsible members of family.

Table 13: Working women reflect in words

$\begin{array}{llll}\text { Frequency } & \text { Percent } & \begin{array}{l}\text { Valid } \\ \text { Percent }\end{array} & \begin{array}{l}\text { Cumulative } \\ \text { Percent }\end{array}\end{array}$




\begin{tabular}{|c|c|c|c|c|}
\hline $\begin{array}{l}\text { How much lucky are the women } \\
\text { who are free to spend their } \\
\text { salaries on } \\
\text { Themselves }\end{array}$ & 91 & 60.7 & 60.7 & 60.7 \\
\hline $\begin{array}{l}\text { You should have spent much on } \\
\text { yourself }\end{array}$ & 59 & 39.3 & 39.3 & 100.0 \\
\hline Total & 150 & 100.0 & 100.0 & \\
\hline
\end{tabular}

Though the working women are spending on family happily by taking the responsibility but there came many moments when they get reflective of this earning and spending process. The $60.7 \%$ of the total respondents are of the view that they inwardly admire the women who spend much on themselves and desire to be like them in financial matters. This high ratio exposes the response of women given in Table 1 where they believed that they spend willingly. It came out that the women who were spending on family willingly were also not happy with this act because they were reflective at the end and admired the women who were free to spend on themselves. This disclosed the biggest truth of Pakistani society where women accepted certain roles consciously and fell a prey to financial manipulation instead of becoming socially out cast.

\section{Conclusion}

In the discriminatory social context, the beliefs about the gender as perceived by the abusive men are often enhanced through the structured policies of institutions. Owing to the lesser understanding about the practice of financial abuses in public, there is lesser comprehension of the social characteristics prevailing and at the same time intersecting with each other. There is scarcityof the research about the financial abuse as lived experiences are shared little.The women need financial control in order to make their dreams true. The manipulative strategies are implied to subjugate women and discourse comes out to be the most effective one. The results declared the fact that the women are conscious of the fact that they are economically abused but they were afraid of the old set notions prevailing in the society that defined stereotypical roles of women and announce the superiority of men. Owing to it, the working women hardly resist this manipulation.

\section{References}

Bhan, G. (2001). India gender profile. Brighton: Institute of Development Studies.

Brewster, M. P. (2003). Power and control dynamics in prestalking and stalking situations. Journal of family violence, 18(4), 207-217.

Chowbey, P. (2017). Women's narratives of economic abuse and financial strategies in Britain and South Asia. Psychology of violence, 7(3), 459.

Evan, S. (2007). Coercive control: How men entrap women in personal life. New York.

Husain, Z., \& Dutta, M. (2014). Women, Work and Exploitation: A Binary Perspective. In Women in Kolkata's IT Sector (pp. 21-48). Springer, New Delhi.

Jury, A., Thorburn, N., \& Weatherall, R. (2017). "What's his is his and what's mine is his": Financial power and economic abuse in Aotearoa. Aotearoa New Zealand Social Work, 29(2), 6982. 
Kishor, S., \& Gupta, K. (2009). Gender equality and women's empowerment in India: National Family Health Survey (NFHS-3), India, 2005-06. Calverton, Maryland, USA: International Institute for Population Sciences.

Littwin A. (2012). Coerced debt: The role of consumer credit in domestic violence. California Law Review, 100, 951-1026.

Miller, M. V. (1995). Intimate terrorism: The deterioration of erotic life. New York: Norton.

Lyon, E. (2002). Welfare and Domestic Violence Against Women. Pennsylvania: National Research Center on Domestic Violence.

Nandi, A. and Platt, L. (2010) Ethnic Minority Women's Poverty and Economic Well-being, London: Government Equalities Office

Qureshi, K. (2016). Marital breakdown among British Asians: Conjugality, legal pluralism and new kinship. Springer.

Rabbani, F., Qureshi, F., \& Rizvi, N. (2008). Perspectives on domestic violence: case study from Karachi, Pakistan. East Mediterr Health J, 14(2), 415-426.

Sharp, N. (2008). What's yours is mine": the different forms of economic abuse and its impact on women and children experiencing domestic violence. London: Refuge.

Smart, C. (2007). Personal life. Cambridge: Polity Press.

Van Dijk, T. A. (2006). Discourse and manipulation. Discourse \& society, 17(3), 359-383.

Wilcox, P. (2006). Surviving domestic violence: Gender, poverty and agency. Springer.

Wodak, R. (1987). 'And where is the Lebanon?'A socio-psycholinguistic investigation of comprehension and intelligibility of news. Text-Interdisciplinary Journal for the Study of Discourse, 7(4), 377-410. 